\title{
A model of salmon louse production in Norway: effects of increasing salmon production and public management measures
}

\author{
Peter Andreas Heuch*, Tor A tle Mo \\ National Veterinary Institute, Fish Health Section, PO Box 8156 Dep., 0033 O slo, N orway
}

\begin{abstract}
Salmon lice Lepeophtheirus salmonis Krøyer have caused disease problems in farmed Atlantic salmon Salmo salar L. since the mid-1970s in N orway. High infection intensities and premature return of wild sea trout Salmo trutta L. were first reported in 1992. Later emaciated wild Atlantic salmon smolts carrying large amounts of lice have been observed both in fjords and offshore. The Norwegian Animal Health Authority regulations to control the problem, which came into operation in 1998, included compulsory louse level monitoring in farms and maximum legal numbers of lice per fish. Here, we present a model of salmon louse egg production in Norway and show that the effect of the current public management strategy is critically dependent on the yearly increase in salmon production. This is because the infection pressure is the product of the number of fish in the system, and the number of lice per fish. Due to the much larger number of farmed than wild salmonids, it is highly likely that lice originating from farmed salmon infect wild stock. Estimated tolerance limits for wild salmonids vary widely, and the level of louse egg production in farms which would be neaded to decimate wild populations is not known. Two possible thresholds for total lice egg production are investigated: (1) 1986 to 1987 level (i.e. before adverse effects on sea trout were recorded), and (2) a level corresponding to a doubling of the estimated natural infection pressure. The farm lice per fish limits that would have to be observed to keep louse production within the 2 thresholds are calculated for the period 1986 to 2005 . A steady decrease in the permitted number of lice per fish may keep the total louse production stable, but the number of salmon required for verification of lice numbers will increase as the prevalence to be verified is decreased. At threshold (2), the model estimated that lice limits should have been 0.05 louse per fish in 1999. This would require 60 fish from each pen to be collected, anaesthetised and examined for a good estimate at a confidence level of $95 \%$. Such sample numbers are likely to be opposed by farmers. The use of national delousing programs to solve the problem is discussed.
\end{abstract}

KEY WORDS: Lepeophtheirus salmonis · Parasite · Louse egg production · Control · M odel

Resale or republication not permitted without written consent of the publisher

\section{INTRODUCTION}

Salmon lice Lepeophtheirus salmonis Krøyer have caused disease problems in farmed Atlantic salmon Salmo salar L. since the mid-1970s in N orway. Adverse effects of salmon lice on wild salmon and sea trout Salmo truttae L. were first reported in 1992 (Urdal 1992), and have now been documented in several fish

*E-mail: peter-andreas.heuch@vetinst.no farming areas (e.g. Birkeland 1996, Grimnes et al. 1998 1999, 2000, Kålås \& Birkeland 1999, Finstad et al. 2000). The apparently increasing problems for wild stocks, and the fact that sal mon farmers continued to take considerable losses due to lice despite novel chemical treatments, made the Norwegian Research Council in 1995 propose a national committee to lay down a strategy for the control of salmon lice in farms. The committee, which included representatives from the Fish Farmers Association, fish veterinarians, research establishments and government officials, put forward their 
recommendations in 1996. Based on these, a working group then proposed the ' $N$ ational Action Plan against Lice on Salmonids'. The main initiatives of the plan were the establishment of regional working groups to co-ordinate efforts to control salmon lice, compulsory monitoring of lice levels in farms, collection of data on wild stock infection, and the introduction of state regulations of maximum levels of lice per fish. The longterm goal of the action plan was to reduce the effects of lice on wild and farmed salmonids to a minimum. The louse monitoring and limits for fish farms came into operation in 1998. The farms should not have more than a mean of 2 adult female lice per fish in the spring, but could have up to a mean of 5 adult females later in the summer and autumn. In February 2000, new limits were set to a mean of 0.5 adult females or 4 mobile lice in total (preadults and/or adult males) for the December to une period.

The question is to what extent the action plan will succeed in achieving the stated goal. That will depend on whether the fish farmers abide by the new regulations, and to what extent the regional working groups are able to co-ordinate delousing. As state regulations use maximum levels of lice per fish, the success of the action plan will also depend on the number of salmonids in the cages, because lice egg output is the product of the number of hosts and the average number of female lice per fish. Norwegian salmon production (in tons) increased by $13 \% \mathrm{yr}^{-1}$ in the period from 1995 to 1999, and the rise is expected to continue. The number of salmon smolts put to sea in 1999 was ca 134 million (Anonymous 2000a), and the total standing stock on 31 December 1999 was 148 million (Norwegian Fisheries Directorate statistics). For optimal management of the aquaculture business, it would seem essential to know how many lice can be tolerated by the wild salmon and sea trout in the area, and which lice limits would be required to keep lice numbers at the desired levels?

In this paper, we present a simple model of salmon louse egg production in Norway. Our objective was to investigate the consequences of a continued increase in the number of salmon louse hosts on the total infection pressure, given that the regulations are followed. Further, we explore the suitability of infection based on 'lice per fish' if a threshold exists beyond which wild stocks of salmonids are affected. Estimated tolerance limits vary widely, and the level of louse egg production in farms which is necessary to decimate wild populations is not known. Two possible thresholds for total lice egg production are investigated: (1) the 1986 to 1987 level (i.e. before adverse effects sea trout stocks were recorded), and (2) a level corresponding to a doubling of the estimated natural infection pressure.

\section{MATERIALS AND METHODS}

Data. The data for the model have been collected from the Norwegian Fisheries Directorate, the Norwegian Directorate for Nature Management, and published reports on louse fecundity, life cycle and natural infection levels.

The model. The model covers the coastal area from and including the county Vest-Agder, at the southernmost tip of Norway $\left(58^{\circ} \mathrm{N}\right)$, to Troms (ca $68^{\circ} 20^{\prime} \mathrm{N}$ ), including Nordland county. Most of Norway's salmon farms are located on this ca $1500 \mathrm{~km}$ long coast. Although the climatic conditions vary widely within the area, the conditions in the counties of Troms and Finnmark further north, which also have Europe's largest salmon rivers, are more extreme. The numerical relationship between farmed and wild salmon is therefore very different in the 2 northernmost counties as opposed to that in the modelled area. The model estimates the total production of adult female salmon lice Lepeophtheirus salmonis Krøyer, and calculates egg production from these females in the period from 1 A pril to $1 \mathrm{~J}$ une. 'Lice' in the following text pertains only to adult female salmon lice. All estimates of wild populations of salmonids are as high as possible, whereas the parameters describing the farmed fish are conservatively estimated. Lice loads on wild salmonids are estimated for a natural, farm-free situation, and are kept constant. Hosts in the farms are Atlantic salmon Salmo salar L. and rainbow trout Oncorhynchus mykiss Walbaum.

The model is based on the following 7 assumptions: (1) The total population of sea-going brown trout Salmo trutta L., excluding smolts, in the following called sea trout, in the model area is estimated to be 1 million. Of these, 700000 were in salt water in the relevant period. These fish have an average of 3 lice fish $^{-1}$ (Schram et al. 1998). (2) No salmon Salmo salar L. have overwintered in salt water on the coast, but 50000 mature salmon have arrived at the coast from the ocean. These fish harbour an average of 10 lice each (J ohannessen, 1975, Berland 1993). (3) There are 1.5 million escaped salmon which carry 10 lice each (Grimnes et al. 1998). (4) The contribution of lice from sea-going Arctic charr Salvelinus alpinus L. is negligible. (5) The number of farmed salmonids in the area in the period can be calculated from official data on standing stock as of $1 \mathrm{~J}$ anuary each year, minus a $20 \%$ loss due to slaughter from $1 \mathrm{~J}$ anuary to $1 \mathrm{M}$ ay. (6) The lice load on these is equal to the official lice limit on the years these are in operation, i.e. the farmed fish have, on average, as many lice as are tolerated by the authorities. (7) Salmon lice from wild hosts have 1000 eggs brood $^{-1}$, and lice from farmed fish have 500 eggs brood ${ }^{-1}$ (Tully \& Whelan 1993). 
The model consisted of simple linked calculations in an MS Excel spreadsheet. It included the following modules: (1) The number of lice on wild hosts $=$ (no. wild salmon $\times 10)+($ no. sea trout $\times 3$ ). (2) The number of lice on farmed hosts $=$ (no. farmed fish in pens) $\times$ (no. lice on farmed fish). (3) The number of lice on escaped hosts $=($ no. escaped fish $) \times 10$. (4) The number of eggs produced on these 3 host groups $=1000 \times$ (no. lice on wild hosts + no. lice on escaped hosts $)+(500 \times$ no. lice on farmed hosts).

Stock numbers: To show historical trends, the louse production was estimated from 1971 present. As stock numbers do not exist for the period prior to 1986 , these were estimated from official total production in tons by multiplying the average for the years 1986 to 1990 by:

\section{No. fish on $1 \mathrm{~J}$ anuary}

\section{Total no. $\mathrm{kg}$ of salmonids slaughtered the same year}

Standing stock of farmed salmonids in Troms and Finnmark counties amounted to $7 \%$ of the total Norwegian stock in 1986. Before this time, the proportion was presumably even smaller as the industry started later in these counties than further south. Good data on the production of salmon in these counties before 1986 are not available. The contributions from Troms and Finnmark were therefore not subtracted from the stock estimates for the period from 1971 to 1985.

The difference between the standing stock on $1 \mathrm{~J}$ anuary and $1 \mathrm{M}$ ay depends on the number of fish being put to sea in the period, mortality due to disease, escapes, discards in sorting, and normal slaughter for sale. As there are neither statistics on the standing stock in May, nor monthly assessments of the factors influencing the number of fish in the pens, the total reduction in numbers in the first 4 mo of the year was set at $20 \%$ of the standing stock on $1 \mathrm{~J}$ anuary.
Projection of lice production: Lice counts do not exist prior to the early 1990s. The estimated numbers of lice per fish in the farms in this period are therefore based on personal communications from fish health veterinarians and biologists who practised at the time, notably Deputy Director T. Håstein (National Veterinary Institute Oslo) and Mr P. Andersen (Flatanger kommune, Lauvsnes). The average number of lice per fish for 1971 to 1979 was set to 10 , for 1980 to 1993 to 4, for 1994 to 1999 to 2, and for 2000 and onwards to 0.5 . The last 2 averages correspond to the current lice limits set by the Department of Agriculture.

Lice production figures for 2000 to 2005 were estimated by assuming a growth of $10 \% \mathrm{yr}^{-1}$ in both the number of fish and production in tons. This rate corresponds to the average tonnage growth in the last $10 \mathrm{yr}$.

Estimates of lice limits: The influence of the number of farmed fish on the louse/fish limits was investigated for 2 total egg production thresholds: (1) Total lice egg production $=50$ billion eggs (estimated production of lice eggs on 1 May 1986 and 1987), and (2) total lice egg production $=5.2$ billion eggs (equal egg production on wild and farmed fish). Estimation of lice limits in the farms, given these thresholds and an increasing production of salmonids, was made by adjusting the limit until the estimated total production was $50 \pm$ 0.3 billion or $5.2 \pm 0.03$ billion eggs $\mathrm{yr}^{-1}$.

\section{RESULTS}

\section{Louse and egg production}

The number of eggs produced by lice on wild salmonids was estimated to be 2.6 billion. In the model, louse production in farms was strongly dependent on
Fig. 1. Model estimates of the standing stock of adult female salmon lice Lepeophtheirus salmonis and the number of eggs produced by these between 1 A pril and $1 \mathrm{~J}$ une from 1971 to 2005, in fish farms in the coastal area between and including the counties of Vest-Agder and Nordland in Norway. Refer to text for details of model calculations

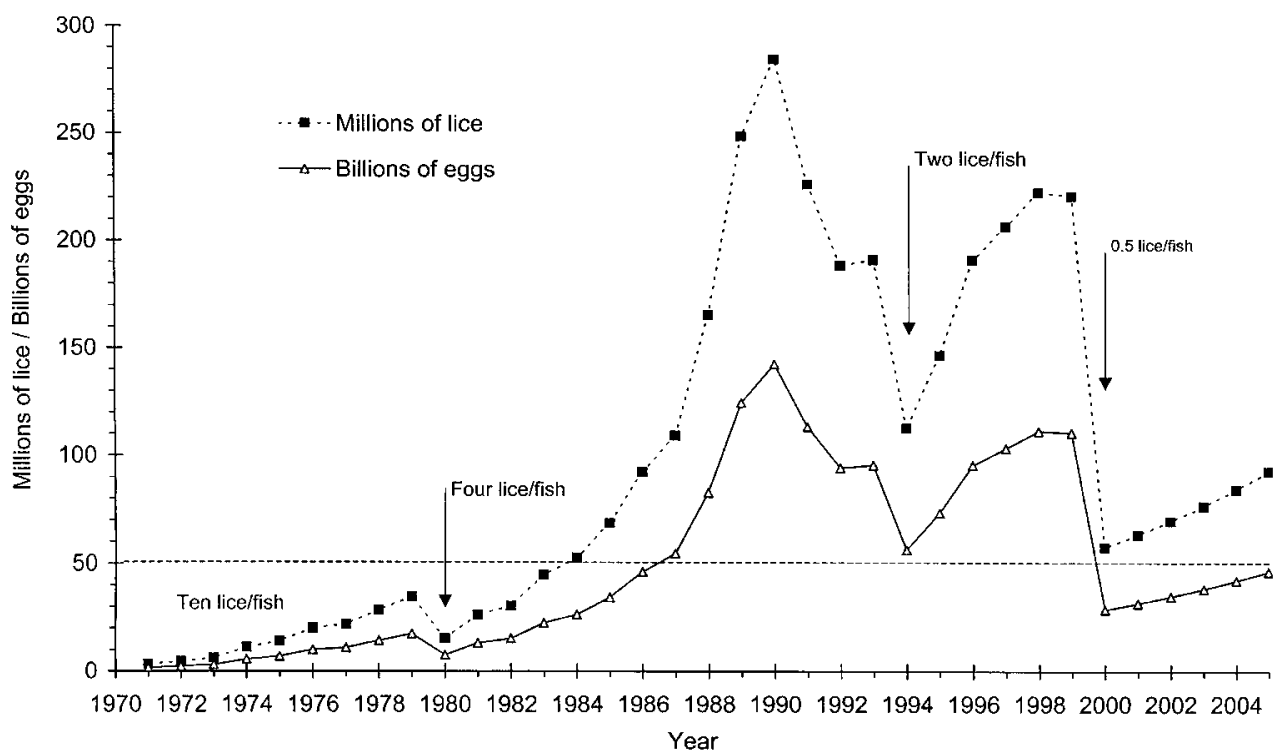




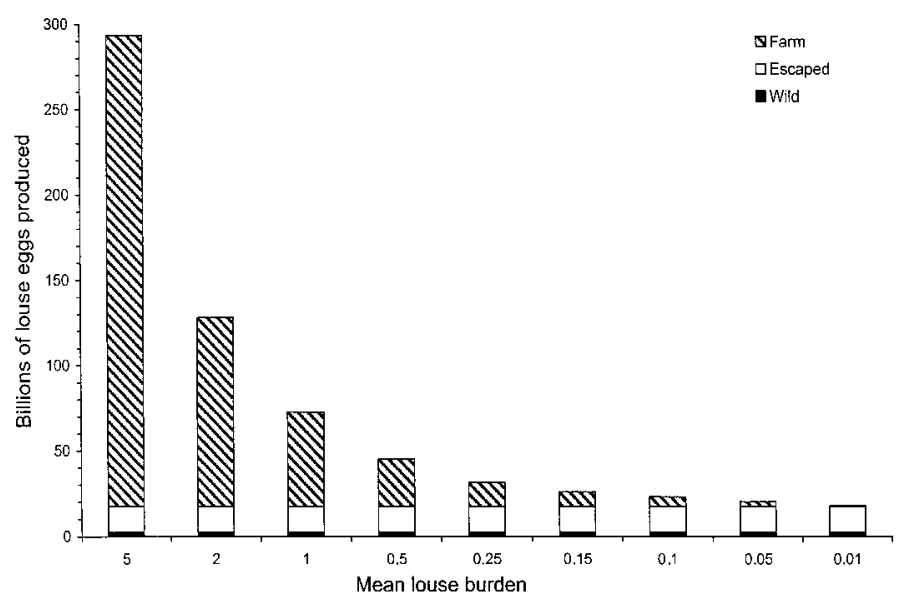

Fig. 2. Model estimates of the number of eggs produced by adult female salmon lice Lepeophtheirus salmonis on different hosts between 1 A pril and 1 J une 1999, in the coastal area between and including the counties of Vest-Agder and Nordland in Norway at different mean farmed-fish louse burdens. Refer to text for details of model calculations

both the limit on lice allowed per farm and the number of fish in the pens. Until the middle of the 1980s the estimated louse production was relatively modest (Fig. 1). Even with an average of 10 adult female lice fish $^{-1}$, the production of louse eggs was well below 30 billion. Starting in about 1986, there was a strong growth in the number of farmed fish, which resulted in a steep rise in the number of lice produced. This was accentuated by the furunculosis epidemic, which induced farmers to put a larger number of fish to sea to maintain production. Estimated louse production peaked in 1990, at 290 million lice and 145 billion eggs. A vaccine against furunculosis was introduced in 1989, but the epidemic was not curbed by vaccination until 1993. Louse egg production then sank rapidly as lower numbers of fish in the pens could now give the same output. The fall from 1993 to 1994 was due to the incorporation in the model of the state limit of 2 adult lice per fish, which was introduced in 1994. In 1995, there was a rise in fish numbers, which caused a steep rise in the production of lice eggs, which peaked in 1998. There was no growth in the number of fish in the farms recorded in 1999, possibly due to losses associated with the viral disease Infectious Pancreas Necrosis (IPN). Louse egg production, based on a $10 \%$ yearly increase in fish numbers and 0.5 lice fish $^{-1}$, is estimated to rise from 29 billion in 2000 to 46 billion in 2005.

At 2 lice fish-1, 111 billion eggs would have been produced in farms from A pril to J une1999 (Fig. 2). This is more than 6 times the number of eggs produced on wild and escaped salmonids together. If farmed fish had carried 0.05 lice on average in 1999, the model predicted that egg production from wild (escapees not included) and farmed salmonids would have been equal. The contribution of louse eggs from escaped fish was estimated to be 15 billion, i.e. 6 times the production on wild salmon and sea trout.

\section{Louse limits as a function of salmon production}

Norwegian production of salmonids has increased by ca $13 \% \mathrm{yr}^{-1}$ on average since 1988 in the area covered by the model (Fig. 3). The influence of the number of farmed fish on the louse per fish limits was investigated for situations where the total lice egg production was 50 billion eggs and 5.2 billion eggs. The model shows that as production rises louse limits must be

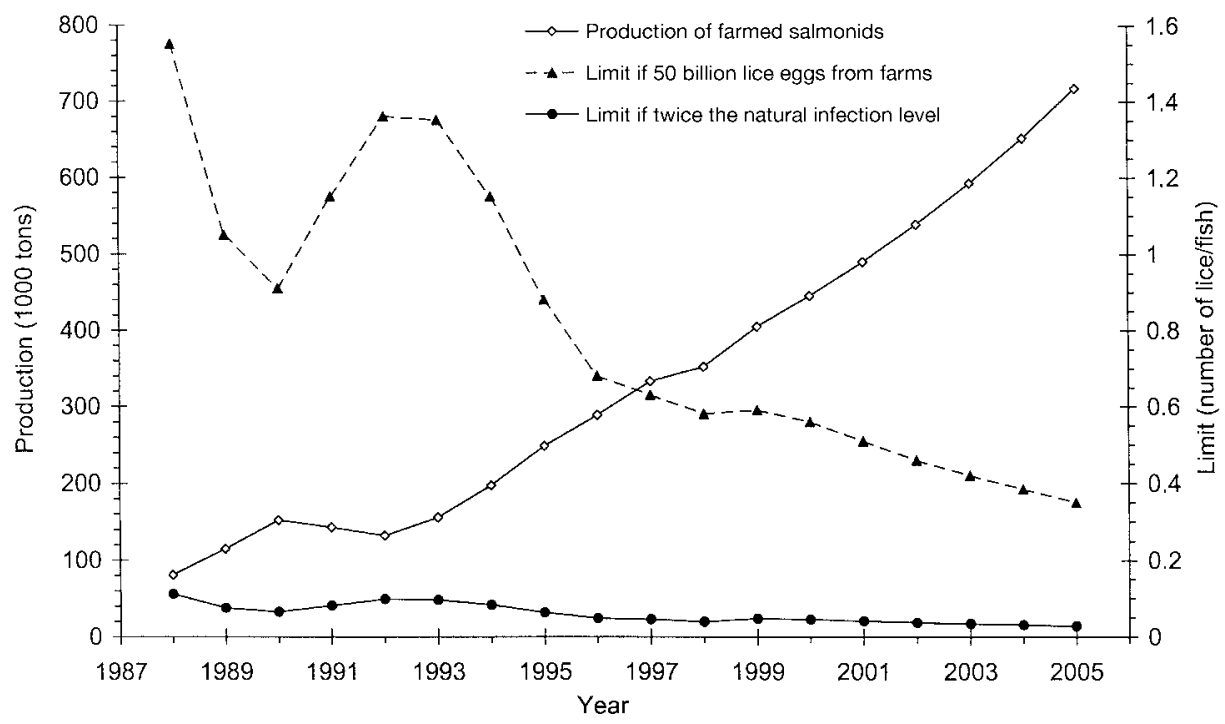

Fig. 3. Production of farmed salmonids in the coastal area between and including the counties of Vest-Agder and Nordland in Norway (data from the Fisheries Directorate, the Fish Farmers Association for 1988 to 1999 , and presuming a $10 \%$ growth from 2000 to 2005), and model estimates of the maximum mean adult female louse Lepeophtheirus salmonis load (=limit) at 2 thresholds of louse egg production: (1) Total production on farmed fish should not exceed 50 billion eggs, and (2) total production on farmed fish should not exceed twice the estimated natural infection level. Refer to text for details of model calculations 
lowered to keep the total egg production constant (Fig. 3). The rise in the calculated 'necessary' limit from 1990 to 1992 reflects the decreasing number of fish put to sea, as noted above. In 2000 , the lice limit should have been 0.6 lice fish $^{-1}$ if total egg production had been held at 50 billion eggs. This is slightly above the 0.5 official limit imposed in February of that year. The model predicts that total louse egg production in 2000 would be very close to the 1986 level if 0.5 lice fish $^{-1}$ was indeed the true average in the farms. To stabilise lice production at this level the limit should be lowered to 0.4 in 2005.

If louse production were not to exceed a level which would be equal to a doubling of the natural infection pressure on wild salmonids (i.e. 2.6 billion eggs from farms), the model suggests that louse limits in farms should have been ca 0.1 lice in 1988, and 0.05 in 1999 (Fig. 1). The estimated louse production in 1988 was estimated to have been 83 billion lice eggs, or 32 times the 'desired' level. In 1999, the model estimated the production to have been 111 billion louse eggs, or 43 times the level that would double the natural infection pressure (Fig. 1).

\section{DISCUSSION}

\section{Assumptions}

In the model, the estimates of wild and escaped populations of salmonids are in the upper end of the range of possible values, whereas the parameters describing the farmed fish are conservatively estimated. This approach was chosen to avoid underestimation of the contribution of wild fish to the pool of salmon lice in the modelled area.

There are no complete statistics on the stock of trout in Norwegian rivers. A report on the disparity between official catch numbers and the actual tonnage of sea trout taken from the N orwegian Skagerrak coast concluded that the official catch could be multiplied by 40 (Gjøseter et al. 1996 ). If this relationship is valid for the whole of the Norwegian coast, the total catch of sea trout may be ca 500 tons, and, assuming a fishing mortality of $30 \%$, the number of sea trout may be estimated to be between 2 and 3 million (B. J onsson, Norwegian Institute for Nature Research, pers. comm.). The stock of overwintering sea trout in the model area may therefore be as large as 1 million. The period from 1 A pril to 1 May covers most of the sea trout runs in most of the model area, but as growth season is negatively correlated with latitude, the trout run later in the northernmost counties (L'A bée-Lund et al. 1989). Elsewhere, the runs may also be extended into J une by adverse weather conditions and lack of water in the rivers. Furthermore, the Skagerrak coasts from the Swedish border to Vest-Agder, an area with a large number of sea trout rivers (Gjøseter et al. 1996), is excluded from the calculations. We have therefore set the number of trout in seawater to 700000 . This excludes smolts, which are uninfected by sea lice when they enter seawater. There are no publications on lice loads of sea trout from the time before salmon farming began. The most extensive study of sea trout as a host for caligid copepods in a natural, farm-free area is from the county of Aust-Agder, which is adjacent to Vest-Agder, the southernmost county included in the present study. Here, sea trout lost most of their lice in the winter, and reappeared in April to $\mathrm{J}$ une with a median of 2 to 3 adult females per infected fish (Schram et al. 1998). Prevalence was between 20 and $45 \%$ in $\mathrm{May}$, and rose through June and July. Recent research has confirmed that an important part of the sea trout stock stays in salt or brackish water through the winter, and serves as hosts for sea lice in this period (P. A. Heuch, unpubl. obs.). The sea louse level in the model was therefore set to 3 lice per seagoing trout.

Salmon do not overwinter in salt water on the coast, but some wild homing salmon may arrive in late spring to early summer to forage before ascending the rivers. The stock of salmon which spawn in rivers in the model area is unknown. Official statistics show that between 150000 and 250000 wild salmon were caught each year on the Norwegian coast from 1990 to 1997 (A nonymous 1999). If $50 \%$ of the fish are caught or lost due to natural mortality, then the number of salmon arriving at the entire Norwegian coastline may approach 500000 . However, a large portion of these spawn in large rivers outside the modelled area such as the Alta, Tana, M ålselva and Numedalslågen. The number of early-arriving salmon was therefore set at 50000 . Lice levels on homing wild and escaped salmon caught in bag-nets have been recorded since 1994. The abundance of adult female lice on wild and escaped fish are not significantly different, and has been stable the last years, at an average of ca 10 lice fish $^{-1}$ (Grimnes et al. 1998, 1999, 2000).

Around $30 \%$ of the salmon caught in bag nets between 1989 to 1997 were escapees (Lund 1998). This indicates that large-scale fish escapes, which before were rather common, now are very rare, but that there is a continuous leakage of fish from the pens (Lund 1998, A nonymous 2000b). The reported number of fish escaping from Norwegian fish farms is ca $600000 \mathrm{yr}^{-1}$ (Anonymous 2000b). However, this number is an underestimate as minor escapes are usually not reported. Currently, most escapes appear to be due to small, handling-related losses (Anonymous 2000b). We have therefore kept the number of escaped fish at a constant 
level. Salmon escaping in the spring and early summer most likely migrate to the North Atlantic and return with the wild salmon to the coast (J onsson et al. 1991). However, they tend to stay for a longer period in salt water before ascending rivers (Lund 1998). Escapees from other times of the year may stay for a longer time at the coast (Hansen \& J onsson 1991). The number of escapees is therefore set higher than the annual escape rate, at 1.5 million $\mathrm{yr}^{-1}$. Lice loads on escaped and wild salmon were set at an average of ca 10 lice fish $^{-1}$ (Grimnes et al. 1998, 1999, 2000).

Arctic charr Salvelinus al pinus can carry salmon lice. However, the anadromous variant of this fish species is common only in the northernmost county in the modelled area, Nordland (J ensen 1981). It descends the rivers as the ice breaks, and stays between only 40 and 55 d in salt water (Mathiesen \& Berg 1968, Nordeng 1977, Berg \& Berg 1989). Its return to fresh water is associated with sea temperatures of ca $10^{\circ} \mathrm{C}$ (Berg \& Berg 1989). Although adult salmon lice are found on the ascending sea charr, the low temperatures would prevent the development of significant amounts of adult lice on this host before it returns to the rivers. The contribution to the total production of louse eggs was therefore regarded as negligible.

The Norwegian Fisheries Directorate started to publish stock numbers of farmed salmonids in 1986, and for the period prior to this we have calculated stock from the yearly production in tons. The conversion ratio was based on the average relationship between yearly production and the calculated stock on 1 May each year for 1986 to 1990 . The conversion depends on mortality in the sea farms. If mortality in this period had exceeded mortality in 1986 to 1990, the number of fish would have been overestimated. Average mortality in 1971 to 1990 fluctuated widely. In the beginning, most Norwegian fish farmers reared rainbow trout, and this species was vulnerable to classic vibriosis (caused by Vibrio anguillarum). A vaccine against vibriosis was introduced in 1977. In the early 1980s, Atlantic salmon became increasingly popular among the farmers, and a previously unknown disease, cold water vibriosis (caused by V. salmonicida), began to cause extensive mortality (M arkestad \& Grave 1997). A vaccine was in place by 1988 . Mortality due to yet another disease, furunculosis (caused by the bacterium Aeromonas salmonicida), was observed in 1986, and this was the most important disease in Norwegian salmon farming until efficient vaccines took effect in 1993 (M arkestad \& Grave 1997). The mortality level in fish farms before 1985 and between 1986 to 1990 are therefore regarded as comparable.

The number of farmed salmonids in the area in 1986 to 2000 was calculated from official data on standing stock as of $1 \mathrm{~J}$ anuary each year, minus $20 \%$ due to natural loss and slaughter from $1 \mathrm{~J}$ anuary to $1 \mathrm{M}$ ay. The difference between the standing stock on $1 \mathrm{~J}$ anuary and 1 May depends on the number of fish being put to sea in the period, mortality due to disease, escapes, discards in sorting and the normal slaughter for sale. Traditionally, few smolts were put to sea in $\mathrm{J}$ anuary, February and $\mathrm{M}$ arch, but this has changed in recent years with light-controlled smoltification giving seawater-ready smolts any time of year. However, as this development is fairly new, and the largest proportion of smolts is put to sea in A pril to November, the number of fish included in the model is not corrected for this stock increase. Mortality due to diseases and escapes was greater before than after 1994 (Anonymous 1996). From 1986 to 1994, losses estimated to be $33 \%$ per generation of fish in the sea, and 17\% in 1995 to 1996 (Anonymous 1996). If the average time in the sea is $18 \mathrm{mo}$, this would give a mortality of ca $2 \% \mathrm{mo}^{-1}$ or $8 \%$ for the period from $1 \mathrm{~J}$ anuary to $1 \mathrm{M}$ ay before 1994, and 1 and $4 \%$, respectively, thereafter. However, this difference would be balanced by the differences between these 2 periods in the yearly production cycle. Before, large quantities of fish were slaughtered at the end of the year, and there was little export at the beginning of the new year. Currently, ca $30 \%$ of the total exported tonnage in each of the years from 1998 to 2000 is slaughtered between J anuary and March (Norwegian Fish Farmers Association web page www.norskfiskeoppdrett.no; Eksportutvalget for fisk). This value does not include the proportion of salmon which is not slaughtered the same year, nor the sale of rainbow trout. In light of the above, the total reduction in numbers in the first 4 mo of the year was set to $20 \%$ of the standing stock on $1 \mathrm{~J}$ anuary.

Counting lice on farmed salmon has been practised only since 1993, when lice caused major losses at several fish farming sites in Norway (J øssund 1995). This was partly due to the lack of knowledge of lice development stages, but also to the fact that any handling of the fish was considered dangerous as it could lead to bacterial diseases. The present study has therefore relied on records from fish health personnel practising in the 1970s and 1980s. Deputy Director Tore Håstein worked with diseases in salmon and rainbow trout farms from the start of the Norwegian fish farming industry, and was for a long time the only veterinarian in Norway specialised in fish. Per Andersen has worked as a counsellor for the salmon farming industry since the end of the 1980s, and was a pioneer in development of lice control procedures.

Since the mid-1990s, there has been a steady reduction in the average lice loads observed in farms ( $P$. A. Heuch unpubl. obs.). Reasons include the disappearance of bacterial diseases, which made the production losses due to lice more visible, a strong pressure from 
environmentalists alarmed by lice damage on wild salmonids, and the availability of better treatments against lice. Consequently, reductions down to 2 and recently 0.5 lice fish $^{-1}$ seemed possible, and the model lice load on the overwintering farmed fish from 1995 to 2005 was set at the official limit. This corresponds to a situation where the farmers, on average, have exactly the official lice limit on their fish.

Several reports indicate that lice from wild hosts have more eggs in each egg string than lice from farmed fish. In Ireland, salmon lice from wild hosts had ca 1000 eggs brood ${ }^{-1}$, and lice from farmed fish had ca 500 eggs brood $^{-1}$ (Tully \& Whelan 1993). Heuch et al. (2000) found that egg strings collected from farm sites and wild salmon in different parts of Norway did not have this clear pattern, though the longest egg strings came from lice on wild fish. Following our cautionary approach, we have included the former numbers (Tully $\&$ Whelan 1993) in the present model. If the farmed fish carry lice with more eggs, our model will underestimate louse egg production.

\section{Louse egg production limits}

Two possible limits for total lice egg production have been investigated. The 1986 to 1987 level of 50 billion eggs was chosen because Norwegian salmon farming at that time was relatively modest (production ca 50000 tons), and adverse effects of lice had not yet been reported in Europe (Urdal 1992, Tully et al. 1993). The results of the present model show that in the period from 1987 to 1993, the average louse egg production was more than twice the 1986 level. When the number of lice in the model is reduced to 2 per farmed fish in 1994, the estimated total louse production returns to the 1994 level within $3 \mathrm{yr}$. This is due to the yearly 10 to $13 \%$ increase in Norway's production of salmon and rainbow trout. M aintaining a total production of 50 billion louse eggs would demand a yearly decrease in the lice limit. According to the model, the official limit in 2005 should be about 0.4, i.e. less than 8 lice per 20 examined fish.

The second limit is based on the tolerance levels of the natural hosts. As these are not well known, it was presumed that hosts could tolerate a doubling of the natural infection pressure without serious effects on mortality. This limit does not take into account the contribution of lice from escaped salmonids, as these are not a part of the imaginary 'natural' system. The model suggests that the production of louse eggs in farms exceeded this limit in 1974. To keep louse egg production at twice the level of the production on wild fish, the model estimated that lice limits should have been 0.05 in 1999. At a prevalence of 5\%, 60 fish from each pen would have to be collected, anaesthetised and examined for a good estimate at a confidence level of 95\% (A nonymous 1997). This is 3 times the standard sample size recommended in the Official Guidelines for lice control from the Norwegian Animal Health Authority (Anonymous 2000c), and would most likely be opposed by fish farmers. Alternatives include acceptance of lower confidence levels, and regional or national delousing campaigns irrespective of lice levels. As outlined above, the choice would depend both on the growth of Norwegian salmon farming and the sustainable threshold louse egg level.

The relative importance of the 3 different host groups for the reproduction of salmon lice changes as lice levels in farms continue to go down (Fig. 2). At an average farm lice count of 0.25 , the largest source of lice eggs would be escapees if the number of fish in this group is kept constant. This means that a program to reduce lice numbers in farms would be reduced, and that measures to prevent farmed fish from escaping probably would result in a stronger reduction of lice infection pressure.

\section{What is a sustainable total louse egg level?}

At present we know very little about which levels of lice may be acceptable in specific areas. It is imaginable that what would be harmful in one fjord could be acceptable in another. Djupvik \& Skjelvan (1999) critically examine the sustainability of the current level of salmon production in the Hardangerfjord, Western Norway. They reach the conclusions that production sites should be redistributed in such a way that there is adequate space between them to prevent spread of diseases, and that a suitable monitoring program must be established to detect trends of disease occurrence in wild and farmed salmonids. It is argued that 'blanket' national or regional delousing should not be implemented, as local conditions can be so different that indiscriminate chemical treatments may lead to the development of resistance in the parasites. Furthermore, Djupvik \& Skjelvan (1999) emphasise that no regional or other level delousing campaigns should be started without careful monitoring of effects. The present model covers most of the salmon-producing coast of Norway, but local models could be made for subsections of this area. Such models would require thorough knowledge of the possible hosts and the parasite abundance on these, and the factors causing changes in the lice levels. Development of local models of this kind would be both rewarding for science, and give authorities the necessary tools for optimal management of coastal systems with regard to pathogens of salmonids. 
Acknowledgements. Thanks are due to Tore Håstein, Per Anderson and Bror J onsson for sharing their knowledge, and to NINA and the Fisheries Directorate for data.

\section{LITERATURE CITED}

Anonymous (1996) Innføring av nye vaksiner i lakseproduksjonen - en konsekvensanalyse. Report. Kontali analyse as, Kristiansund $\mathrm{N}$

Anonymous (1997) Diseases of fish - general information. In: Diagnostic manual for aquatic animal diseases. Organisation Internationale des Epizooties, Paris, p 6

Anonymous (1999) Til laks åt alle kan ingen gjera? Norges Offentlige Utredninger 1999, Statens forvaltningstjeneste, Oslo

Anonymous (2000a) Årsberetning og regnskap 1999. Norske Fiskeoppdretteres Forening, Trondheim

Anonymous (2000b) Nasjonal tiltaksplan mot rømming. Report Norske Fiskeoppdretteres Forening, Trondheim

Anonymous (2000c) Retningslinjer for telling, registrering og rapportering av lus. Appendix 6. In: Eithun I, Baarøy V, Postmyr E, Gullaksen AS, J ensen F, Mo M: Nasjonal handlingsplan mot lus på laksefisk. Resultatrapport 1999. Tiltaksplan for perioden 2000-2001. Statens Dyrehelsetilsyn, Oslo

Berg OK, Berg M (1989) Sea growth and time of migration of anadromous arctic char (Salvelinus alpinus) from the Vardnes River, in Northern Norway. Can J Fish Aquat Sci 46:955-960

Berland B (1993) Salmon lice on wild salmon in Norway. In: Boxshall GA, Defaye D (eds) Pathogens of wild and farmed fish: sea lice. Ellis Horwood Limited, Chichester, p 179-187

Birkeland K (1996) Consequences of premature return by sea trout (Salmo trutta) infested with the salmon louse (Lepeophtheirus salmonis Krøyer): migration, growth and mortality. Can J Fish Aquat Sci 53:2808-2813

Djupvik HO, Skjelvan A (1999) Produksjon av laksefisk i Hardangerfjorden: Kva er mogeleg innafor ei berekraftig ramme? N orsk Fiskeoppdrett 18/99:30-31

Finstad B, Bjørn PA, Grimnes A, Hvidsten NA (2000) Laboratory and field investigations of salmon lice [Lepeophtheirus salmonis (Krøyer)] infestations on Atlantic salmon (Salmon salar L.) post-smolts. Aquacult Res 11:795-803

Gjøseter J, Knutsen J A, Knutsen H, Aass A, Sollie A (1996) Beskatning av sjøørret i sjø på Skagerrakkysten og i Oslofjorden (Et forprosjekt). Fisker og Havet, Vol 7, 1996, Institute of Marine Research, Bergen

Grimnes A, Finstad B, Bjørn PA, Tovslid BM, Lund RA (1998) Registreringer av lakselus på laks, sjøørret og sjørøye $\mathrm{i}$ 1997 NINA. Oppdragsmelding 525. Norwegian Institute for Nature Research, Trondheim

Grimnes A, Finstad B, Bjørn PA (1999) Registreringer av lakselus på laks, sjøørret og sjørøye i 1998. NINA (Nor Inst Nat Res). Oppdragsmelding 579:1-33

Grimnes A, Finstad B, Bjørn PA (2000) Registreringer av lakselus på laks, sjøørret og sjørøye i 1998. NINA. Oppdragsmelding 634. Norwegian Institute for Nature Research, Trondheim

Editorial responsibility: Wolfgang Körting, Hannover, Germany
Hansen LP, J onsson B (1991) The effect of timing of Atlantic salmon smolt and post-smolt release on the distribution of adult return. Aquaculture 98:61-67

Heuch PA, Nordhagen J R, Schram TA (2000) Egg production in the salmon louse [Lepeophtheirus salmonis (Krøyer)] in relation to origin and water temperature. Aquacult Res 31:805-814

J ensen J W (1981) A nadromous arctic char, Salvelinus al pinus, penetrating southward on the Norwegian coast. Can J Fish Aquat Sci 38:247-249

J ohannessen A (1975) Lakselus, Lepeophtheirus salmonis Krøyer (Copepoda, Caligidae). Frittlevende stadier, vekst og infeksjon på laks (Salmon salar L.) fra oppdrettsanlegg og kommersielle fangster i vestnorske farvann 1973-1974. Candidatus Realium thesis, University of Bergen, Norway, p 1-113

J onsson B, Jonsson N, Hansen LP (1991) Differences in life history and migratory behaviour between wild and hatchery-reared Atlantic salmon in nature. Aquaculture 98:69-78

J øssund TJ B (1995) Lusetellinger som ledd i helsetjeneste for fiskeoppdrett. Norsk Veterinærtidskrift 107:114-119

Kålås S, Birkeland K (1999) Registreringer av lakselus på sjøaure i Hardangerfjorden og på Sotra i Hordaland sommaren 1998. Rådgivende Biologer AS Report 388:1-20

L'A bée-Lund J H, J onsson B, J ensen A.J , Sættem LM, Heggberget TG, J ohnsen BO, Næsje TF (1989) Latitudinal variation in life-history characteristics of sea-run brown trout Salmo trutta. J Anim Ecol 58:525-542

Lund RA (1998). Rømt oppdrettslaks i sjø- og elvefisket $i$ årene 1989-1997. NINA. Oppdragsmelding 556. Norwegian Institute for Nature Research, Trondheim

Markestad A, Grave K (1997) Reduction of antibacterial drug use in Norwegian fish farming due to vaccination. In: Gudding R, Lillehaug A, Midtlyng PJ , Brown F (eds) Fish vaccinology. Karger, Basel, p 365-369

Mathisen OA, Berg M (1968) Growth rates of the char Salvelinus alpinus (L.) in the Vardnes River, Troms, northern N orway. Rep Inst Freshw Res Drottninghl 48:177-186

Nordeng H (1977) A pheromone hypothesis for homeward migration in anadromous salmonids. Oikos 28:155-159

Schram TA, Knutsen J A, Heuch PA, Mo TA (1998) Seasonal occurrence of Lepeophtheirus salmonis and Caligus elongatus (Copepoda: Caligidae) on sea trout (Salmo trutta), off southern Norway. ICES J M ar Sci 55:163-175

Tully O, Whelan KF (1993) Production of nauplii of Lepeophtheirus salmonis (Krøyer) (Copepoda: Caligidae) from farmed and wild salmon and its relation to the infestation of wild sea trout (Salmo trutta L.) off the west coast of Ireland in 1991. Fish Res 17:187-200

Tully O, Poole WR, Whelan KF, M erigoux S (1993) Parameters and possible causes of epizootics of Lepeophtheirus salmonis Krøyer infesting sea trout (Salmo trutta L.) off the west coast of Ireland. In: Boxshall GA, Defaye D (eds) Pathogens of wild and farmed fish: sea lice. Ellis Horwood Limited, Chichester, p 202-213

Urdal K (1992) Omfanget av lakselus på vill laksefisk i fylka Nordland, Nord- og Sør-Trøndelag, Møre og Romsdal og Sogn og Fjordane. Report Zoological Museum, Dept of Animal Ecology, University of Bergen

Submitted: October 17, 2000; Accepted: February 21, 2001 Proofs received from author(s): M ay 21, 2001 